\title{
Competency Achievement of Physical Education, Sports and Health Teachers in High Schools of Padang Pariaman
}

\author{
Masrudi Suryanto ${ }^{1}$ Erizal Nurmai ${ }^{2}$ \\ Student of Magister Sport Education \\ Universitas Negeri Padang \\ Rudioke2385@gmail.com
}

\begin{abstract}
The problem in this study is obstacles in carrying out the duties of physical educators, thus affecting their performance in producing competitive students. The purpose of this study was to determine the performance achievements of physical education, sports, and health teachers in state junior high schools in Padang Pariaman Regency. This research is descriptive quantitative research with a survey method, an instrument in the form of a questionnaire. Data analysis uses descriptive quantitative
\end{abstract}

\section{INTRODUCTION}

Education is something that is a basic need in nation and state development. "education is a conscious and planned effort to create an atmosphere of learning and learning process so that students actively develop their potential to have spiritual spiritual strength, self-control, personality, intelligence, noble character and the skills required by himself, the community, nation and state "[1].

"sports education is physical education and sports are carried out as part of an organized and continuing education process to obtain knowledge, personality, skills, health, and physical fitness"[1].

Physical education in sports and health, make a very significant contribution to the overall education of children both attitude, physical and knowledge of children. To be effective in the learning process, which is the relationships and activities that occur between students and educators in achieving educational goals, it should be supported by the competencies of the teacher.

"teacher competencies include, a, pedagogical competencies, b, personality competencies, c, social competencies, d, professional competencies"[2]. Teachers who have competence will produce good performance, then the goals of national education will be achieved.

Teacher competence is; "A teacher's ability to carry out obligations responsibly and properly"[3].

Data compiled from the West Sumatra LPMP on July 12, 2019 about the results of the sports competence and physical education teacher competency tests (UKG) that carry out tasks in Padang Pariaman District, out of 101 people who took UKG who passed only 3 people $(2.97 \%)$ statistical methods. In this study, physical and sports education teachers as objects, while the subjects were 52 junior high school principals in Padang Pariaman Regency. The results showed that the achievement of the competence of sports and health physical education teachers (PJOK) in SMP Negeri Padang PariamanRegency in the Good category.

Keywords-Competence, Teacher PJOK, Performance

, and 98 people (97.03) did not pass this shows that the level of competency of PJOK teachers in Padang Pariaman Regency is still low.

If we see these results, of course this will affect the performance of teachers in teaching and learning activities carried out by teachers in the classroom and in the field. In TrisMardiyiko's research the results of his research "There is a positive and significant contribution between teacher competence and the performance of Salatiga City Middle School teachers" This means that competence influences the performance of PJOK teachers.

Information obtained from several teachers who took the PJOK MGMP teaching in junior high schools in Padang Pariaman District and the results of talks with several principals of junior high schools at the MKKS Junior High School meeting in Padang Pariaman, on 15 July 2019 said that the Physical Education and Sports teachers Health still experiences many obstacles in carrying out its duties during the learning process, which is among them there are PJOK teachers teaching not guided by the RPP and Syllabus that have been prepared. The RPP that is compiled is sometimes only stored on a Plasdisk or $\mathrm{CD}$ as a handle. They still teach in a monotonous way, as if the material about the sepkabola they only give the ball to students and tell them to play without regard to whether the playing techniques and basic techniques displayed by students are true or false. After learning takes place, the average PJOK teacher does not evaluate the learning process that has just taken place. So students do not know where the mistakes they made and cause the goals of learning are not achieved as they 
should. PJOK teachers also have the ability to master less skilled classes.

This can be seen when the learning hours are taking place, the teacher is less able to control the classroom atmosphere because in the presentation of learning the lack of modifying learning so that when the teacher explains the learning many of the students seem indifferent and are not interested in the material delivered by the teacher. This disinterest is not derived from the material being taught, but occurs because the teacher has not been able to control classroom structure properly. In addition there are still among these teachers who come to school not on time and the PJOK teacher is also less able to make himself a special teacher in front of students, peers, parents of students and the community. This is caused by the inability of the PJOK teacher to socialize and communicate well.

From the condition of the facts and data obtained, it shows that the PJOK Junior High School teacher has not shown the maximum quality of competence in teaching. To see more clearly whether the true achievement of PJOK Junior High School Teacher Competencies in Padang Pariaman Regency is not optimal, it is necessary to obtain empirical data. Therefore to find out the good or bad of the Competency Achievement of Sports and Health Physical Education Teachers (PJOK) in teaching, of course, a study must be conducted, the research revealing about "Achievement of the Competency of Physical Education and Sports Physical Education Teachers in Padang Pariaman Regency.

\section{METHOD}

Research methods are basically scientific ways to obtain data with specific purposes and uses. The method used in this study is a quantitative method with survey and experimental techniques which are types of quantitative research[4].

Based on research that researchers have done some time ago regarding the Competency Achievement of PJOK teachers in State Junior High Schools in Padang Pariaman District, the respondent achievement level (TCR) was $65.31 \%$ with the category "Good". This explains that the PJOK teacher Competency Achievement in State Junior High Schools in Padang Pariaman Regency can already be said to be good even though the number shown in the percentage of earnings is still low.

Based on data obtained from respondents from 52 junior high school principals, it can be seen the competency achievement of PJOK junior high school teachers in Padang Pariaman Regency per each indicator, namely :

\section{Pedagogical Competence}

Pedagogical competence is about how the teacher's ability to teach. this capability includes the ability to manage learning, which includes understanding students, designing and implementing learning, evaluating learning outcomes, and developing students to actualize their various potentials [5].

This pedagogic competency is related when the teacher conducts teaching and learning in the classroom. Starting from making learning scenarios, choosing methods, media, as well as evaluation tools for their students. Because after all in the teaching and learning process most of the learning outcomes of students are determined by the role of the teacher. An intelligent and creative teacher will be able to create an atmosphere of effective and efficient learning so that learning does not go in vain. It is said that what is meant by the teacher's performance in the teaching and learning process is the ability or ability of teachers to create an atmosphere of educational communication between teachers and students that includes cognitive, effective, and psychomotor aspects as an effort to learn something based on planning up to the evaluation and follow-up stages so that achieved teaching objectives.

So this pedagogical competence relates to the ability of teachers in the teaching and learning process that is the preparation of teaching which includes designing and implementing learning scenarios, choosing methods, media, and evaluation tools for students to achieve educational goals in the cognitive, effective, and psychomotor domains of students

\section{RESULTS AND DISCUSSION}

Based on the results of research on the results of the PJOK teacher competency achievement, especially on pedagogical competency indicators researchers found that the level of respondent achievement, in this case the PJOK teacher in Padang Pariaman Regency was $65.18 \%$, based on the percentage of competency achievement found in the "Good" classification.

\section{Personality Competencies}

Personality is an abstract problem that can only be seen through one's appearance, actions, speech, and manner of dress. Everyone has a different personality. Personality competence is a personal performance (traits) that must be possessed by a teacher. A teacher must have a personality that is: (a) steady, (b) stable, (c) mature, (d) wise, (e) authoritative, (f) noble, and ( $g$ ) can be role models. A teacher must have a dual role. The role is realized in accordance with the situations and conditions encountered. Sometimes teachers must empathize with their students and sometimes teachers must be critical. Empathizing means that the teacher must patiently deal with the desires of his students, they must protect and 
serve their students, but on the other hand the teacher must also be firm if there are students doing wrong.

The teacher's personality will determine the teacher's order in carrying out their duties, especially Islamic religious education teachers, not only as a basis for teachers to behave, but also become models for their students in their development. Therefore, the personalities of the teachers are fostered and developed as well as possible, teachers especially Islamic religious education teachers are expected to be able to show the qualities of good personality traits, such as honest, open, affectionate, helpful, patient, cooperative, independent and so on.

Based on the results of research that has been done by researchers about the achievement of teacher personality competencies, researchers found that the level of achievement of respondents on this indicator is in the classification of "Good" or with a percentage of $65.02 \%$.

\section{$3 . \quad$ Social Competence}

Teachers are individuals who are part of the community. The teacher needs others to fulfill his needs and carry out his role as a teacher and educator. What is meant by other people here can be students, education staff in schools and institutions, and the community in general where a teacher lives. The role and behavior of a teacher in school and in the community will always be monitored by others, both students, fellow education staff and the community. Here the teacher's behavior will be made an example, in other words the teacher as a role model. In Javanese sentences that the teacher was innocent and imitated. Digugu means followed by the words of his advice and imitated means followed by his behavior.

Social competence is an ability of a teacher in terms of communicating and interacting effectively with: (a) students, (b) fellow educators, (c) educational staff, (d) parents / guardians of students and (e) surrounding communities, while the ability of a teacher to make contact with a person or society is called social intelligence or social intelligence and is one of the nine intelligences consisting of logic, language, music, body, space, personal, nature, and culinary. The intelligence possessed by a person works in an integrated and simultaneous manner when someone thinks and or does something related to a person or social community group.

The teacher is tasked with creating a pleasant learning climate so students can learn comfortably and happily. Student creativity can be developed if the teacher does not dominate the learning communication process, but the teacher teaches more, giving inspiration so that they can develop creativity through various learning activities so that students gain a variety of learning experiences. It can provide psychological freshness in receiving information.
This is where the process of individualization and the process of socialization in educating.

Based on the results of research that researchers have done about the achievement of social competence of teachers, researchers find that the level of achievement of respondents on this indicator is in the classification of "Good" or with a percentage of $65.50 \%$.

As individuals engaged in education, teachers must have personalities that reflect an educator. The demands for personality as educators are sometimes felt more severe than in other professions. The phrase that is often used is that "teachers can be manipulated and imitated". Digugu means that the messages conveyed by the teacher can be trusted to be implemented and their lifestyle can be imitated or emulated. For this reason, teachers must recognize the values that are adhered to and developed in the community where they carry out their assignments and live. If there are values that conflict with the values they hold, then he must react with the right things so there is no conflict of values between the teacher and the community. If there is a conflict between the two it will result in disruption of the education process. Therefore, a teacher must have social competence so that later when differences in values occur with the community, he can solve them well so as not to hamper the educational process.

4. Professional Competence

Professional competence is the broad and deep empowerment of learning material that enables it to guide students to meet the competency standards set by the National Education Standards Agency (BNSP). This is an ability of a teacher in accordance with his expertise in conveying something to students in order to carry out their duties and profession. The work of a teacher is a profession that cannot be done by just anyone. The teaching profession has the principles [2]

Based on the results of research that researchers have done about the achievement of professional competence of teachers, researchers find that the level of respondents' achievement on this indicator is in the classification of "Good" or with a percentage of $65.56 \%$.

Teacher professionalism competency is related to the competence that requires the teacher to be an expert in the field of education as a foundation in carrying out his profession as a professional teacher. Because in carrying out the teaching profession, there is a basic ability in the knowledge of learning and human behavior, the field of study he fosters, attitudes ang right about teaching and learning environment and have skills in teaching techniques.

Professional competence means "The teacher must have extensive and deep knowledge about the subject matter (field of study) to be taught, as well as mastery of 
methodology in the sense of having theoretical concept knowledge, being able to choose the right method, and being able to use it in the teaching and learning process". Therefore in this study what is meant by professional competence is the ability of teachers in mastery of subject matter and the ability of teachers in managing learning. Learning management in question is an understanding of students, learning implementing plans, mastery of learning methods and media as well as assessment of learning outcomes.

In education, the teacher is an educator, mentor, coach, and leader who can create an attractive learning climate, provide a sense of security, comfort and conducive to the classroom. Its presence in the midst of students can dilute the atmosphere of stiffness, stiffness, and boredom of learning that feels hard to be accepted by students. Such conditions certainly require the skills of a teacher, and not all are able to do it. Realizing that, the authors assume that the teacher's existence professional is very necessary.

Based on the results of the competency achievements that have been analyzed per indicator, it can be seen that the achievement of the competencies of PJOK Junior High School teachers in Padang Pariaman Regency per indicator in the percentage is almost the same, which is around $65 \%$.

\section{CONCLUSION}

Based on the results of research that has been done by researchers about the achievement of PJOK Teachers Competence in Junior High Schools in Padang Pariaman District, the level of respondent achievements based on the analysis of the principal obtained results of $65.31 \%$. which is in the "Good" classification. The following are the results of PJOK teacher competencies per indicator:

1. In the pedagogical competency indicator the level of achievement of respondents obtained by PJOK teachers in State Junior High Schools in Padang Pariaman Regency is in the classification of "Good" with a percentage of $65.18 \%$.

2. In the personality competency indicator, the level of respondent achievement obtained by PJOK teachers in SMP Negeri Se Padang Pariaman Regency is in the classification of "Good" with a percentage of $65.02 \%$.

3. In the social competency indicator the level of respondent achievements obtained by PJOK teachers in SMP Negeri Se Padang Pariaman Regency is in the classification of "Good" with a percentage of $65.50 \%$.

4. In the professional competency indicator the level of respondent achievement obtained by PJOK teachers in SMP Negeri Se
Padang Pariaman Regency is in the classification of "Good" with a percentage of $65.56 \%$.

\section{REFERENCES}

[1] Undang-Undang Republik Indonesia No. 20 Tahun 2003 tentang Sistem Pendidikan Nasional. 2003, pp. 25.

[2] Undang-Undang Republik Indonesia No.14 tahun 2005 tentang: Guru dan Dosen. Jakarta: Pemerintah Republik Indonesia. 2005, pp. 34.

[3] M. Usman. "Menjadi Guru Profesional". Bandung: Rosdakarya. 2009, pp. 89.

[4] Sugiyono. "Statistika untuk Penelitian". Bandung: Alfabeta. 2011, pp. 56.

[5] Peraturan Pemerintah Republik Indonesia Nomor. 19 Tahun 2005 tentang Standar Pendidikan Nasional. 2005, pp. 78. 